\title{
Synthesis and investigation on optical and electrochemical properties of 2,4-diaryl-9-chloro-5,6,7,8-tetrahydroacridines
}

\author{
Najeh Tka ${ }^{1,2}$, Mohamed Adnene Hadj Ayed ${ }^{1}$, Mourad Ben Braiek ${ }^{1}$, Mahjoub Jabli ${ }^{3}$ \\ and Peter Langer ${ }^{*} 2,4, \S$
}

\author{
Full Research Paper \\ Address: \\ ${ }^{1}$ Laboratory of Asymmetric Synthesis and Molecular Engineering for \\ Organic Electronic Materials (LR18ES19), Monastir University, \\ Faculty of Sciences of Monastir, Environment street, 5019 Monastir, \\ Tunisia, ${ }^{2}$ Universität Rostock, Institut für Chemie, Albert-Einstein-Str. \\ 3a, 18059 Rostock, Germany, ${ }^{3}$ Department of Chemistry, College of \\ Science Al-zulfi, Majmaah University, Al-Majmaah, 11952, Saudi \\ Arabia, and ${ }^{4}$ Leibniz-Institut für Katalyse e.V. an der Universität \\ Rostock, Albert-Einstein-Str. 29a, 18059 Rostock, Germany

\section{Email:} \\ Peter Langer * peter.langer@uni-rostock.de \\ * Corresponding author \\ § Fax: +49 381498 6412; phone: +49 381498 6410; \\ web: http://www.langer.chemie.uni-rostock.de \\ Keywords: \\ catalysis; cross-coupling; cyclization; fluorescence; palladium

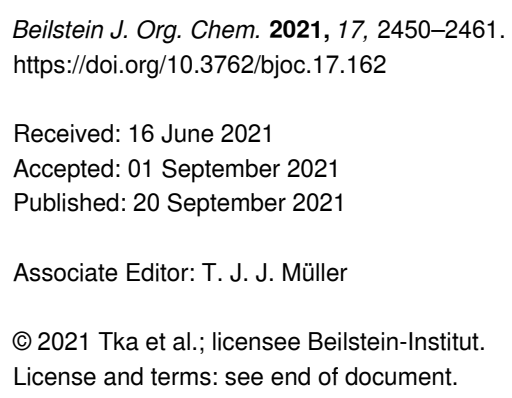


received much attention in medicinal chemistry, due to their ability to inhibit topoisomerase enzymes and block the DNA transcription $[44,45]$. In particular, they have been widely explored for the treatment of Alzheimer's disease [46-51], human cancer [52,53], and tuberculosis [54] (Figure 1).

Taking into consideration the significant medicinal potential of tetrahydroacridines and the lack of knowledge concerning their optoelectronic properties, the search for new candidates is of ongoing interest. Recently, considerable attention has been given to acridines in our laboratory and we developed new synthetic methods for dibenzoacridines and acridones based on Pd-catalyzed cross-coupling reactions [55,56]. More recently, we have reported the synthesis of alkynylated 5,6,7,8-tetrahydroacridines [57]. In continuation to our previous work and as a part of our interest in new organic materials [58-60], we report herein the synthesis of hitherto unknown 2,4-diaryl-9chloro-5,6,7,8-tetrahydroacridine derivatives and their optical and electrochemical properties investigation by the use of UV-vis and emission spectroscopy, CV measurements as well as DFT calculations.

\section{Results and Discussion}

Synthesis. At the beginning of this study, we synthesized 2,4 dibromo-9-chloro-5,6,7,8-tetrahydroacridine (2) by refluxing 3,5-dibromoanthranilic acid (1) [61] with cyclohexanone in $\mathrm{POCl}_{3}$ through an adapted reported procedure [62] (Scheme 1).

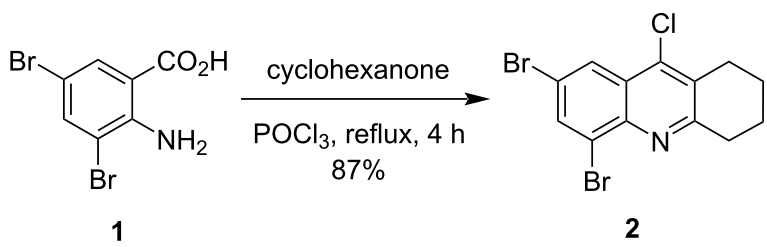

Scheme 1: Synthesis of 2

With precursor 2 in hand, we intended to expand the $\pi$-conjugation of the tetrahydroacridine core by adding diversely substituted aryl groups using the Suzuki-Miyaura cross-coupling reaction $[63,64]$. As a model reaction, we studied the coupling between 2,4-dibromo-9-chloro-5,6,7,8-tetrahydroacridine (2) and phenylboronic acid (3a). After a thorough optimization using $\mathrm{Pd}\left(\mathrm{PPh}_{3}\right)_{4}$ as catalyst, toluene as solvent, and $\mathrm{K}_{3} \mathrm{PO}_{4}$ as base, the desired bis-arylated product $4 \mathbf{a}$ was isolated in up to $91 \%$ yield. The trifold Suzuki-Miyaura coupling product, i.e., 2,4,9-triphenyl-5,6,7,8-tetrahydroacridine, could not be prepared, even after increasing the amount of phenylboronic acid to 4 equivalents and prolonging the reaction time.

Our primary screening consisted in evaluating the effect of the catalyst amount. Several attempts were performed showing that a low concentration of the catalyst was required to avoid the formation of elevated amounts of homocoupling and side products. We found that reducing the amount of $\mathrm{Pd}\left(\mathrm{PPh}_{3}\right)_{4}$ from $5 \mathrm{~mol} \%$ to $1 \mathrm{~mol} \%$ gave higher yields of 2,4-diphenyl-9chloro-5,6,7,8-tetrahydroacridine (4a) (Table 1, entries 1-6). Towards a better understanding of the regioselectivity of the coupling, we carried out a series of experiments with decreased amounts of phenylboronic acid. In all cases, the cross-coupling took place at both bromine atoms of $\mathbf{4 a}$ and we could never isolate the corresponding monoarylated coupling product. The replacement of $\mathrm{Pd}\left(\mathrm{PPh}_{3}\right)_{4}$ by $\mathrm{PdCl}_{2}\left(\mathrm{PPh}_{3}\right)_{2}$ afforded $4 \mathbf{a}$ in almost the same yield (Table 1, entries 5 and 7). Concerning the impact of the base, we found that the application of $\mathrm{K}_{2} \mathrm{CO}_{3}$ or $\mathrm{Cs}_{2} \mathrm{CO}_{3}$ instead of $\mathrm{K}_{3} \mathrm{PO}_{4}$ did not lead to an improvement of the yield (Table 1, entries 8 and 9). However, increasing the amount of $\mathrm{K}_{3} \mathrm{PO}_{4}$ to 4 equivalents gave a nearly quantitative yield (Table 1, entry 12 ). We believe that a supplementary activation of the boronic acid, by adding a high amount of base, improved the nucleophilicity and facilitated the transmetalation. The use of dioxane instead of toluene (Table 1, entry 11) gave again a very good yield $(89 \%)$. However, the employment of THF resulted in a decreased yield (Table 1, entry 10). The best result for the Suzuki-Miyaura cross-coupling between $\mathbf{2}$ and 3a was obtained using $1 \mathrm{~mol} \%$ of $\mathrm{Pd}\left(\mathrm{PPh}_{3}\right)_{4}$ and 4 equivalents of $\mathrm{K}_{3} \mathrm{PO}_{4}$ in toluene at $100{ }^{\circ} \mathrm{C}$ for 4 hours.

With our optimized conditions in hand, we examined the scope of the reaction of $\mathbf{2}$ with other arylboronic acids $\mathbf{3 b}-\mathbf{g}$ (Scheme 2).<smiles>Nc1c2c(nc3ccccc13)CCCC2</smiles>

tacrine<smiles>Nc1c2c(nc3ccccc13)CCCC2O</smiles>

velnacrine<smiles>COc1cc2c(cc1OC)CN(CCc1ccc(NC(=O)c3cccc4c(=O)c5cccc(OC)c5[nH]c34)cc1)CC2</smiles>

elacridar

Figure 1: Some important tetrahydroacridines used as drugs. 
Table 1: Optimization of the Suzuki-Miyaura coupling between 2 and $3 \mathbf{a}^{\mathrm{a}}$<smiles>Clc1c2c(nc3c(Br)cc(Br)cc13)CCCC2</smiles>

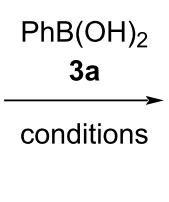

(c)

\begin{tabular}{|c|c|c|c|c|c|}
\hline entry & catalyst & [mol \%] & base & solvent & yield $^{\mathrm{b}}(\%)$ \\
\hline 1 & $\mathrm{Pd}\left(\mathrm{PPh}_{3}\right)_{4}$ & 5 & $\mathrm{~K}_{3} \mathrm{PO}_{4}$ & toluene & 60 \\
\hline 2 & $\mathrm{Pd}\left(\mathrm{PPh}_{3}\right)_{4}$ & 4 & $\mathrm{~K}_{3} \mathrm{PO}_{4}$ & toluene & 67 \\
\hline 3 & $\mathrm{Pd}\left(\mathrm{PPh}_{3}\right)_{4}$ & 3 & $\mathrm{~K}_{3} \mathrm{PO}_{4}$ & toluene & 71 \\
\hline 4 & $\mathrm{Pd}\left(\mathrm{PPh}_{3}\right)_{4}$ & 2 & $\mathrm{~K}_{3} \mathrm{PO}_{4}$ & toluene & 82 \\
\hline 5 & $\mathrm{Pd}\left(\mathrm{PPh}_{3}\right)_{4}$ & 1 & $\mathrm{~K}_{3} \mathrm{PO}_{4}$ & toluene & 91 \\
\hline 6 & $\mathrm{Pd}\left(\mathrm{PPh}_{3}\right)_{4}$ & 0.5 & $\mathrm{~K}_{3} \mathrm{PO}_{4}$ & toluene & 84 \\
\hline 7 & $\mathrm{PdCl}_{2}\left(\mathrm{PPh}_{3}\right)_{2}$ & 1 & $\mathrm{~K}_{3} \mathrm{PO}_{4}$ & toluene & 90 \\
\hline 8 & $\mathrm{Pd}\left(\mathrm{PPh}_{3}\right)_{4}$ & 1 & $\mathrm{~K}_{2} \mathrm{CO}_{3}$ & toluene & 88 \\
\hline 9 & $\mathrm{Pd}\left(\mathrm{PPh}_{3}\right)_{4}$ & 1 & $\mathrm{Cs}_{2} \mathrm{CO}_{3}$ & toluene & 87 \\
\hline 10 & $\mathrm{Pd}\left(\mathrm{PPh}_{3}\right)_{4}$ & 1 & $\mathrm{~K}_{3} \mathrm{PO}_{4}$ & THF & 75 \\
\hline 11 & $\mathrm{Pd}\left(\mathrm{PPh}_{3}\right)_{4}$ & 1 & $\mathrm{~K}_{3} \mathrm{PO}_{4}$ & dioxane & 89 \\
\hline 12 & $\mathrm{Pd}\left(\mathrm{PPh}_{3}\right)_{4}$ & 1 & $\mathrm{~K}_{3} \mathrm{PO}_{4}$ (4 equiv) & toluene & 95 \\
\hline
\end{tabular}

aReagents and conditions: catalyst, base, 2 ( $0.5 \mathrm{mmol}), 3 a(1.1 \mathrm{mmol})$, solvent $(5 \mathrm{~mL}), 100{ }^{\circ} \mathrm{C}, 4 \mathrm{~h}$; ${ }^{\text {is }}$ isolated yield.<smiles>Clc1c2c(nc3c(Br)cc(Br)cc13)CCCC2</smiles>

2<smiles>[R]Oc1cc[R](O)cc1</smiles>

$3 \mathbf{a}-\mathbf{g}$ $\mathrm{R}=\mathrm{OMe}, \mathrm{OCF}_{3}, \mathrm{Et}$, and $\mathrm{Ph}$

$\underset{\mathrm{K}_{3} \mathrm{PO}_{4}(4 \text { equiv })}{\stackrel{\mathrm{Pd}\left(\mathrm{PPh}_{3}\right)_{4}(1 \mathrm{~mol} \%)}{\longrightarrow}}$ toluene, $100{ }^{\circ} \mathrm{C}, 4 \mathrm{~h}$<smiles></smiles><smiles>Clc1c2c(nc3c(-c4ccccc4)cc(-c4ccccc4)cc13)CCCC2</smiles><smiles>COc1ccc(-c2cc(-c3ccc(OC)cc3)c3nc4c(c(Cl)c3c2)CCCC4)cc1</smiles><smiles>FC(F)(F)Oc1ccccc1</smiles><smiles>FC(F)(F)Oc1ccc(-c2cc(-c3ccccc3)cc3c(Cl)c4c(nc23)CCCC4)cc1</smiles><smiles>COc1ccccc1-c1cc(-c2ccccc2OC)c2nc3c(c(Cl)c2c1)CCCC3</smiles>

4d $(92 \%)$

4b $(97 \%)$<smiles>CCc1ccc(-c2cc(-c3ccc(CC)cc3)c3nc4c(c(Cl)c3c2)CCCC4)cc1</smiles><smiles>Clc1c2c(nc3c(-c4ccccc4-c4ccccc4)cc(-c4ccccc4-c4ccccc4)cc13)CCCC2</smiles>

$4 f(85 \%)$<smiles>CCc1ccccc1-c1cc(-c2ccccc2CC)c2nc3c(c(Cl)c2c1)CCCC3</smiles>

$\mathbf{4 g}(88 \%)$

Scheme 2: Synthesis of compounds $\mathbf{4 a - g}$. 
As expected, we found that electron-donating groups located in the arylboronic acid improved the yield. The cross-coupling of $\mathbf{2}$ with arylboronic acids $\mathbf{3 b}$ and $\mathbf{3 d}$, bearing a methoxy group in position 2 or 4 , afforded the corresponding products $\mathbf{4 b}$ and $\mathbf{4 d}$ in excellent yields. Arylboronic acids containing an alkyl group in different positions afforded good yields for products $\mathbf{4 e}$ and 4g. With the substrate containing a trifluoromethoxy group $\left(\mathrm{OCF}_{3}\right)$, a longer reaction time of 6 hours was required to obtain the product $\mathbf{4 c}$ in decreased yield $(57 \%)$.

Photophysical properties. We studied the steady-state absorption and emission of selected tetrahydroacridines $4 \mathbf{a}-\mathbf{d}$ to gain insights into their photophysical properties. The UV-vis absorption spectra were measured in diluted dichloromethane solutions $\left(c=1 \times 10^{-5} \mathrm{M}\right)$ at room temperature. Table 2 summarizes the obtained spectral data, fluorescence quantum yields, stokes shifts, and optical band gap energies.

As shown in Figure 2, most of the compounds show a broad band at around 320-360 $\mathrm{nm}$ in the UV region assigned to the $\pi-\pi^{*}$ electronic transitions. The phenyl unsubstituted derivative 4a exhibited a main wide band with a shoulder peak at $329 \mathrm{~nm}$. Derivatives $\mathbf{4 b}$ and $\mathbf{4 d}$, bearing methoxy substituents, showed similar optical absorptions to those of $\mathbf{4 a}$ with slight red shifts. In case of the trifluoromethoxy-substituted derivative $\mathbf{4 c}$, a larger red shift of $23 \mathrm{~nm}$ was observed. The optical gap energies of tetrahydroacridines $4 \mathbf{a}-\mathbf{d}$ were estimated from the onset point of the absorption spectra [65]. The parent derivative $4 \mathbf{a}$ shows an onset of absorption at $363 \mathrm{~nm}$ and its optical band gap was deduced to be around $3.37 \mathrm{eV}$. Derivatives $\mathbf{4 b}$ and $\mathbf{4 d}$ showed similar values of $3.20 \mathrm{eV}$ and $3.18 \mathrm{eV}$, respectively. In contrast, compound $\mathbf{4 c}$ showed a decreased value of $3.09 \mathrm{eV}$.

The emission spectra of tetrahydroacridines 4 a-d were measured with an excitation line at $325 \mathrm{~nm}$. They were dominated by broad bands ranging from 365 to $500 \mathrm{~nm}$ (Figure 3). The emission spectrum of $\mathbf{4 a}$ appeared as a blue emission at $393 \mathrm{~nm}$. Trifluoromethoxy derivative $\mathbf{4 c}$ exhibited a red shift of $10 \mathrm{~nm}$ as compared to $\mathbf{4 a}$. Methoxy derivatives $\mathbf{4 b}$ and $\mathbf{4 d}$

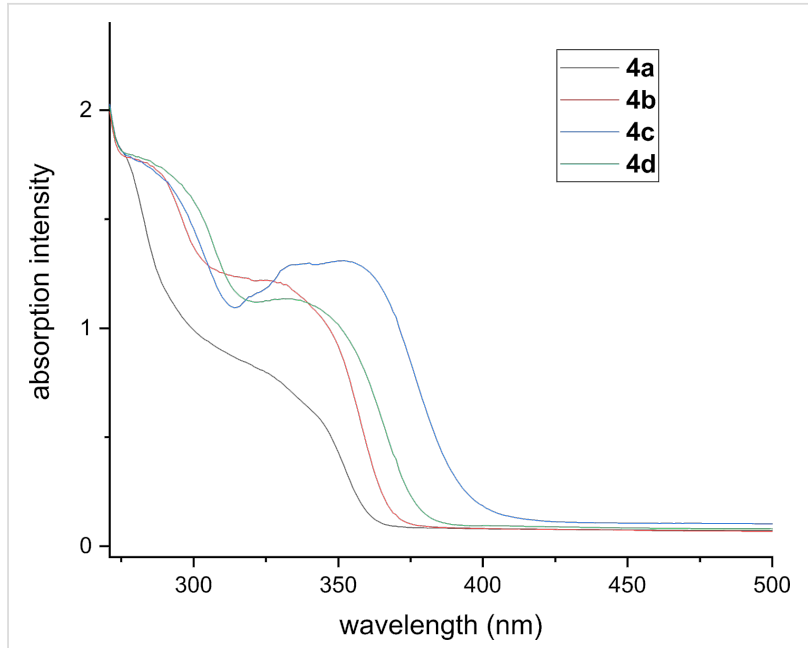

Figure 2: UV-vis absorption spectra of $\mathbf{4 a - d}$ at room temperature in dilute dichloromethane solutions $\left(c=1 \times 10^{-5} \mathrm{M}\right)$.

showed similar emission bands at around $410 \mathrm{~nm}$ and gave larger red shifts. Their bands at lower energy may be attributed to the intramolecular charge transfer (ICT) from the electrondonating methoxy groups to the tetrahydroacridine core.

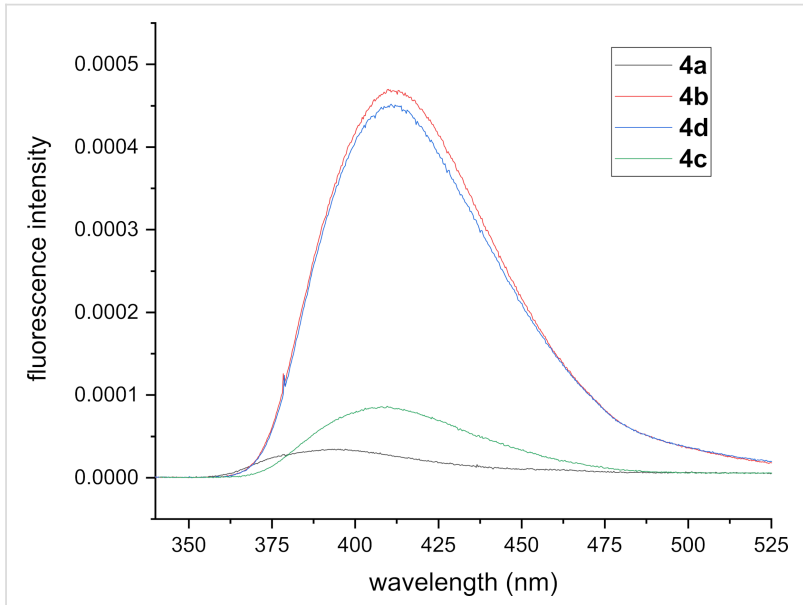

Figure 3: Fluorescence spectra of $4 a-d$ at room temperature in dilute dichloromethane solutions $\left(c=1 \times 10^{-5} \mathrm{M}\right)$.

\begin{tabular}{|c|c|c|c|c|c|c|c|c|}
\hline \multirow[b]{2}{*}{ compound } & \multicolumn{4}{|l|}{ emission } & \multicolumn{4}{|l|}{ absorption } \\
\hline & $\lambda_{\mathrm{em}}(\mathrm{nm})$ & $\mathrm{FWHM}^{\mathrm{a}}$ & $\phi_{\text {fluo }}{ }^{\mathrm{b}}(\%)$ & $\tilde{\mathrm{v}}$ stokes $^{\mathrm{c}}$ & $\lambda_{\mathrm{abs}}(\mathrm{nm})$ & $\log \varepsilon$ & $\lambda_{\text {onset }}(\mathrm{nm})$ & $E_{\mathrm{g}}^{\mathrm{opt}}(\mathrm{eV})^{\mathrm{c}}$ \\
\hline $4 a$ & 393 & 57 & 1.1 & 4854 & 329 & 4.88 & 367 & 3.37 \\
\hline $4 b$ & 410 & 61 & 8.2 & 5730 & 332 & 5.07 & 387 & 3.20 \\
\hline $4 c$ & 406 & 67 & 1.5 & 3778 & 352 & 511 & 401 & 3.09 \\
\hline $4 d$ & 409 & 62 & 7.8 & 5580 & 333 & 5.05 & 389 & 3.18 \\
\hline
\end{tabular}

aspectrum full width at half maximum $(\mathrm{nm})$; b fluorescence standard: quinine bisulfate in $1 \mathrm{~N} \mathrm{H}_{2} \mathrm{SO}_{4}\left(\phi_{\mathrm{fluo}}=0.54\right)$; ${ }^{\mathrm{c}} \mathrm{Stokes}$ shift in wavenumber $\left(\mathrm{cm}^{-1}\right)=\left(1 / \lambda_{\mathrm{abs}}{ }^{\mathrm{max}}-1 / \lambda_{\mathrm{em}}{ }^{\mathrm{max}}\right) \cdot 10^{7} ;{ }^{\mathrm{d}}$ estimated from the onset point of the absorption spectra: $E_{\mathrm{g}}{ }^{\mathrm{opt}}=1240 / \lambda_{\mathrm{onset}}$. 
The Stokes shifts of $\mathbf{4 a - d}$ were calculated based on their absorption and emission spectra. Derivative $\mathbf{4 b}$, containing an electron-donating methoxy substituent in para-position, gave the highest value of $5770 \mathrm{~cm}^{-1}$. The fluorescence quantum yields of 4a-d were calculated with a comparative method, where quinine sulfate (SQ) in $0.1 \mathrm{M} \mathrm{H}_{2} \mathrm{SO}_{4}$ was used as standard [66].

The fluorescence and absorbance spectra for quinine sulfate and product $\mathbf{4 b}$ are given in Figure 4 and Figure 5, respectively. In addition, their plots of fluorescence intensities against absorbances are shown in Figure 6A and 6B. The tetrahydroacridine derivative $\mathbf{4 b}$ gave the highest fluorescence quantum yield of $8.2 \%$.
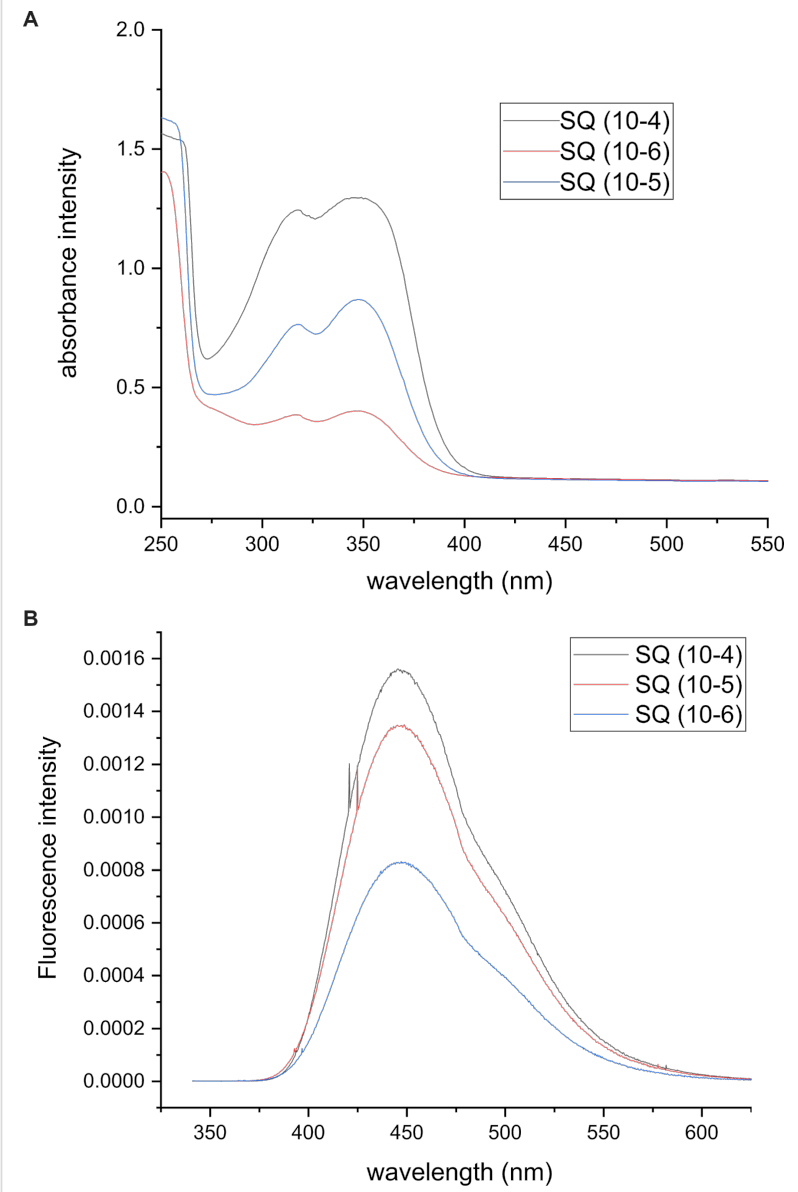

Figure 4: A) Absorbance and B) emission spectra for the standard quinine sulfate (SQ).

In order to elucidate the experimental observations and to further study the electronic properties, DFT calculations were carried out on the fully ground state at the restricted B3LYPlevel with 6-31G(d) basis set using dichloromethane as a continuum solvent model. The optimized chemical structures of

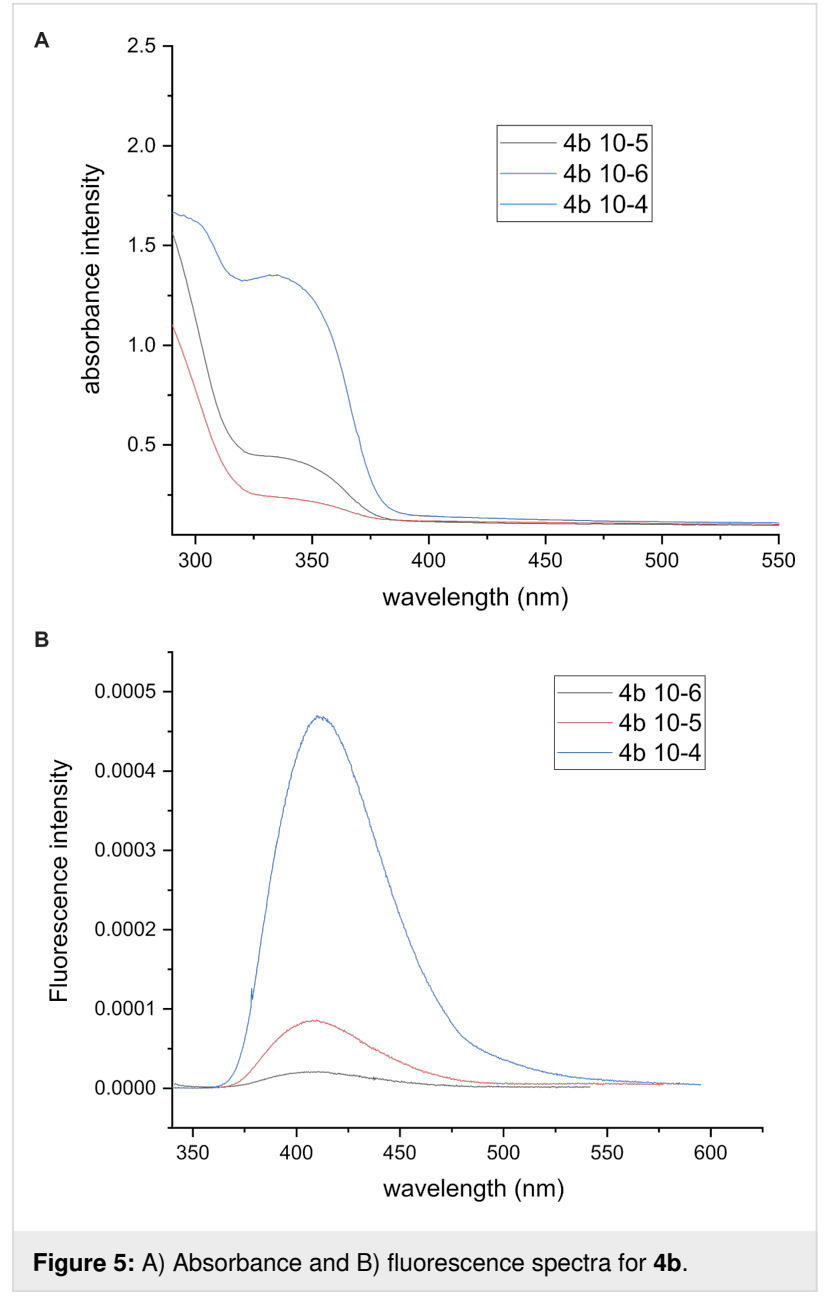

4a-d are given in Figure 7 with selected geometrical parameters including dihedral angles and bonding and non-bonding distances (Table 3). It can be seen from Figure 7 that the four obtained structures are non-planar, due to steric hindrance and electronic repulsions. For compound 4a, considerable distortions of -38.61 and -49.60 degrees between the tetrahydroacridine plane and the two phenyl groups were observed, due to rotations around the $\mathrm{C}-2$ and $\mathrm{C}-4$ single bonds. These torsion angles did not change significantly for products $4 \mathbf{b}$ and $4 \mathbf{c}$ bearing two substituents located at the para-positions. However, when the substituents were methoxy groups located at the ortho-positions, the dihedral angles were larger with values of -45.66 and -58.22 degrees, presumably due to steric reasons. These geometries may affect the electronic parameters of tetrahydroacridines 4a-d and particularly their band gap energies.

On the other hand, the photophysical properties of products 4e-g were not significantly affected by the aryl substituent. Electronic effects of the alkyl group were, as expected, very weak and no significant additional distortions arise from a paraor ortho-ethyl group for products $\mathbf{4 e}$ and $\mathbf{4 g}$. Therefore, they 

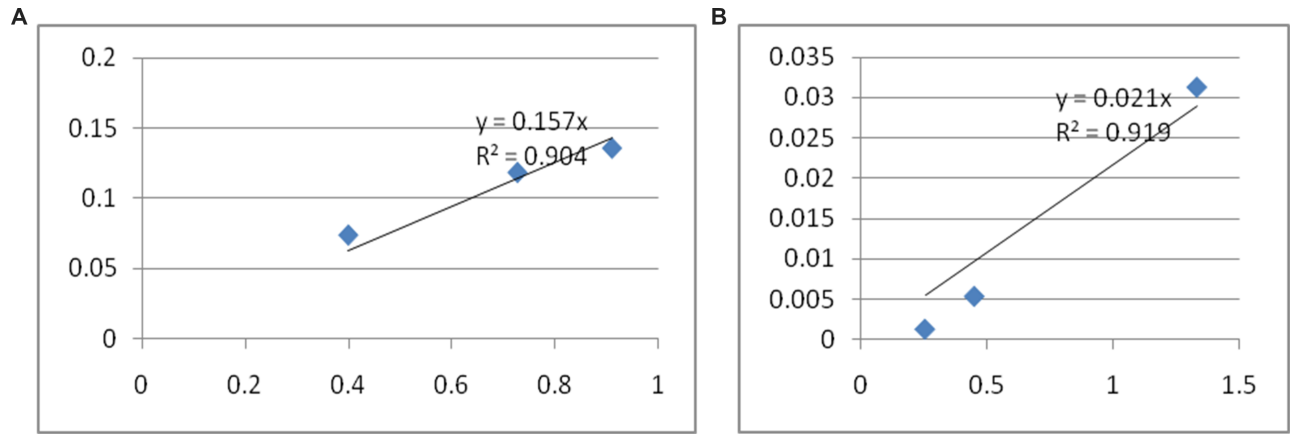

Figure 6: A) Plot of fluorescence intensities against their absorbances for quinine sulfate (SQ) and B) plot of fluorescence intensities against their absorbances for compound $\mathbf{4 b}$.

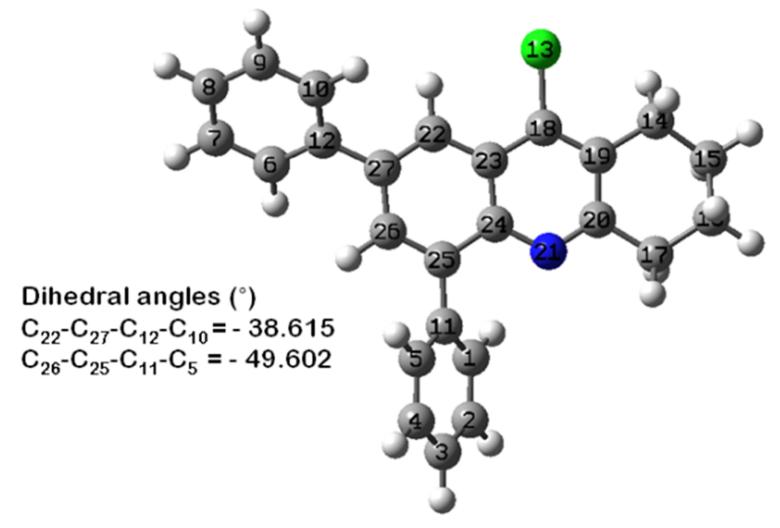

$4 a$

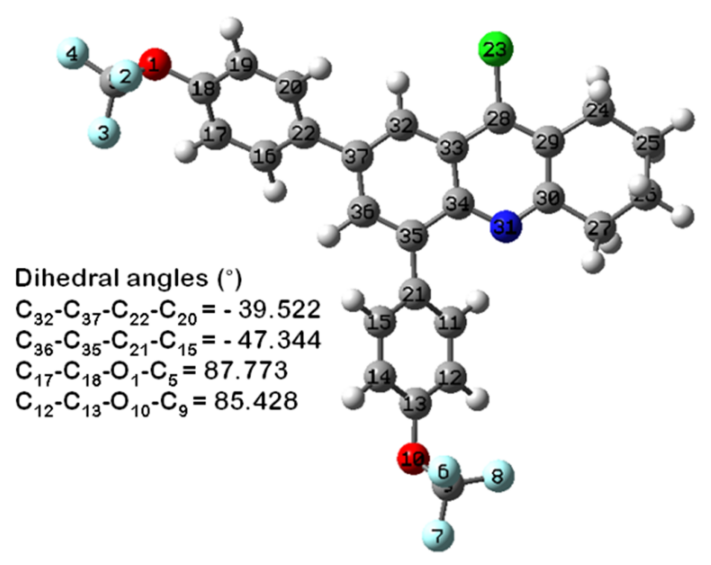

4c

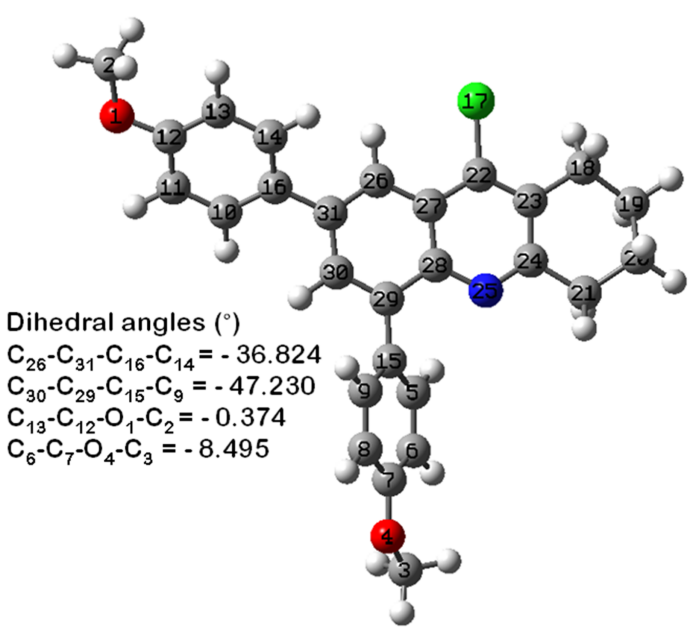

4b

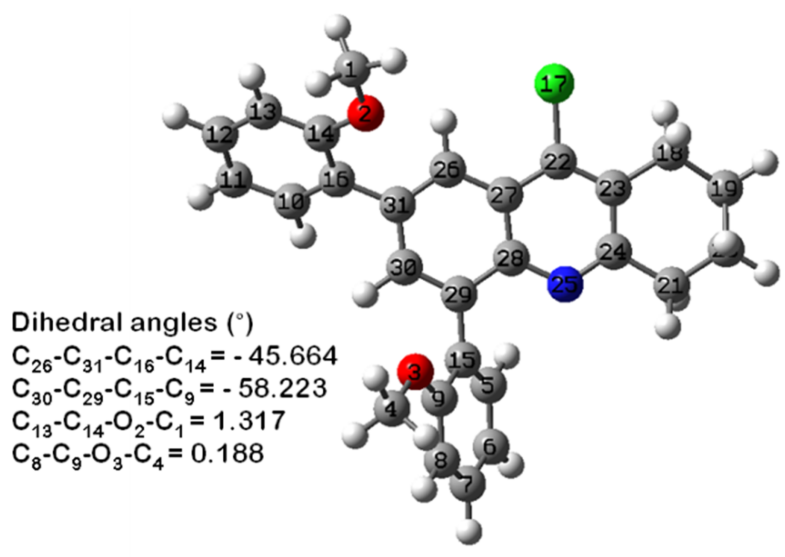

4d

Figure 7: Selected dihedral angles $\left(^{\circ}\right)$ for compounds $4 a-d$.

gave the same absorption and emission as the parent product $\mathbf{4 a}$ As well, the phenyl ortho-substituent in the aryl ring for $\mathbf{4 f}$ was twisted out of the plane and was not involved in the electronic orbital distribution (Figure 8).
As shown in Figure 9, the HOMO and LUMO frontier orbitals of products $\mathbf{4 a}-\mathbf{d}$ are extended over the $\pi$-conjugated part of the molecules and, as expected, the cyclohexane ring is not involved. In all cases, the electron densities of HOMO were 


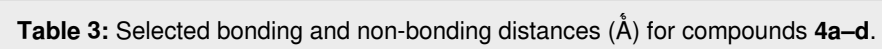

\begin{tabular}{lllll} 
& 4a & 4b & 4c & 4d \\
\hline bonding distances $(\AA)$ & $\mathrm{C}_{27}-\mathrm{C}_{12}=1.4853$ & $\mathrm{C}_{31}-\mathrm{C}_{16}=1.4833$ & $\mathrm{C}_{37}-\mathrm{C}_{22}=1.4850$ & $\mathrm{C}_{31}-\mathrm{C}_{16}=1.4884$ \\
& $\mathrm{C}_{25}-\mathrm{C}_{11}=1.4883$ & $\mathrm{C}_{29}-\mathrm{C}_{15}=1.4862$ & $\mathrm{C}_{35}-\mathrm{C}_{21}=1.4879$ & $\mathrm{C}_{29}-\mathrm{C}_{15}=1.4906$ \\
non-bonding distances $(\AA)$ & $\mathrm{C}_{22}-\mathrm{C}_{10}=3.0201$ & $\mathrm{C}_{26}-\mathrm{C}_{14}=3.0200$ & $\mathrm{C}_{32}-\mathrm{C}_{20}=3.0229$ & $\mathrm{C}_{26}-\mathrm{C}_{14}=3.1294$ \\
& $\mathrm{C}_{26}-\mathrm{C}_{5}=3.0036$ & $\mathrm{C}_{30}-\mathrm{C}_{9}=2.9963$ & $\mathrm{C}_{36}-\mathrm{C}_{15}=3.0021$ & $\mathrm{C}_{30}-\mathrm{C}_{9}=3.1216$ \\
& $\mathrm{~N}-\mathrm{C}_{1}=2.9923$ & $\mathrm{~N}-\mathrm{C}_{5}=2.9778$ & $\mathrm{~N}-\mathrm{C}_{11}=2.9782$ & $\mathrm{~N}-\mathrm{C}_{5}=3.0248$
\end{tabular}

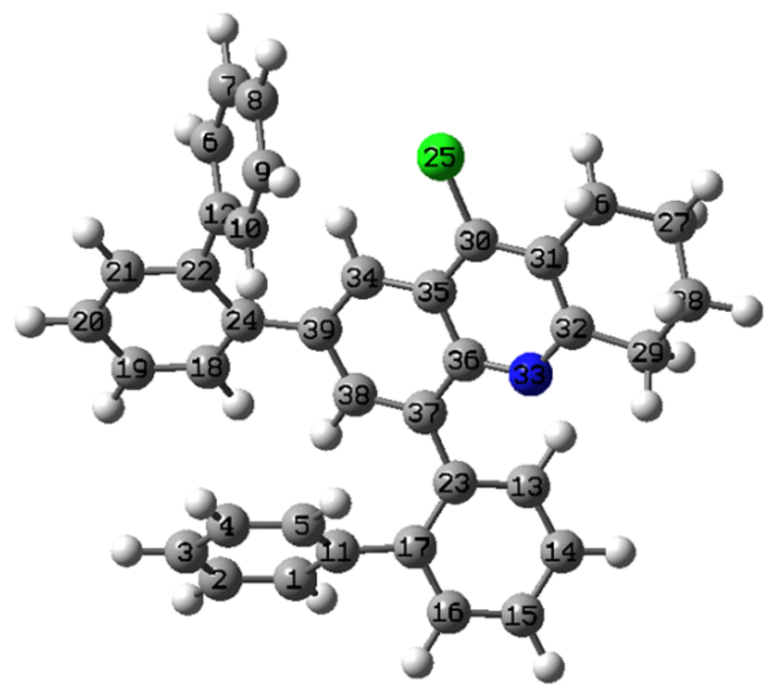

Dihedral angles $\left({ }^{\circ}\right)$

$\mathrm{C}_{24}-\mathrm{C}_{22}-\mathrm{C}_{12}-\mathrm{C}_{10}=-72.416$

$\mathrm{C}_{23}-\mathrm{C}_{17}-\mathrm{C}_{11}-\mathrm{C}_{5}=-56.813$

$\mathrm{C}_{34}-\mathrm{C}_{39}-\mathrm{C}_{24}-\mathrm{C}_{22}=-19.708$

$\mathrm{C}_{38}-\mathrm{C}_{37}-\mathrm{C}_{23}-\mathrm{C}_{17}=-35.415$

Figure 8: Selected dihedral angles $\left({ }^{\circ}\right)$ for compound $\mathbf{4 f}$.

localized in the $\pi$-bonding orbitals between the carbon backbone of the quinoline ring and its two external phenyls. The LUMO electron densities were mainly located in the $\pi^{*}$ antibonding orbitals outside the carbon cores. It was observed for compound $\mathbf{4} \mathbf{c}$ that the two trifluoromethoxy groups were twisted out of the plane and consequently did not participate in the orbital distribution. The HOMO electronic distributions of $\mathbf{4 b}$ and $\mathbf{4 d}$ were spread over the two non-twisted methoxy groups.

The calculated values of HOMO, LUMO, and the band gap energies of compounds $\mathbf{4 a - d}$ at the B3LYP level of theory with 6-31G(d) basis set using dichloromethane as a continuum solvent model are given in Figure 9. The energy gap values are affected by the type and the position of the substituent located at the phenyl groups. In fact, different values of $3.87 \mathrm{eV}$ and
$4.06 \mathrm{eV}$ were observed for compounds $\mathbf{4 b}$ and $\mathbf{4 d}$ having a methoxy group at the ortho- or para-positions, respectively. The electron-withdrawing trifluoromethoxy groups in compound $\mathbf{4 c}$ lead to a decrease in the HOMO energy to $-6.10 \mathrm{eV}$ and LUMO energy to $-1.86 \mathrm{eV}$ giving an energy gap of $4.02 \mathrm{eV}$. The HOMO energy of derivative $\mathbf{4 b}$ was the highest and as a result it exhibited the lowest value of $E_{\text {gap }}$ and its electron conductivity was the best.

The molecular electrostatic potential maps for tetrahydroacridines 4a-d are shown in Figure 10. The red and blue colors visualize the region of the attractive and repulsive potential, respectively. For the phenyl-substituted derivative 4a, the bluecolored surface, located mainly at the cyclohexane ring, visualizes the electron deficiency (high electrostatic potential). The red regions, localized essentially at the nitrogen atom and at the two external phenyl groups, show the electron abundance (low electrostatic potential). The trifluoromethoxy group for $\mathbf{4 c}$ resulted in a decrease of electron density in the tetrahydroacridine core. In addition, this strong electron-withdrawing effect induced the appearance of blue surfaces around the phenyl groups leading to a significant decrease in their electronic densities. However, thanks to the $\pi$-donating effect of two methoxy groups for $\mathbf{4 b}$ and $\mathbf{4 d}$, yellow-red regions are present in the phenyl groups and quinoline core.

The electrochemical behavior of compound $\mathbf{4 c}$ was studied by cyclic voltammetry (CV) in dry acetonitrile. The obtained voltammogram, recorded at a scanning rate of $50 \mathrm{mV} / \mathrm{s}$, is given in Figure 11. The HOMO and LUMO energy levels were deduced from the onset potentials of the oxidation and reduction waves, respectively. The potential of the saturated $\mathrm{Ag} / \mathrm{AgCl}$ reference electrode was calibrated using the ferrocene/ferrocenium $(\mathrm{Fc} / \mathrm{Fc}+)$ redox system [67], the HOMO and LUMO energies were calculated by using the following equations:

$$
\begin{aligned}
& E_{\mathrm{HOMO}}(\text { ionization potential })=-\left(V_{\text {onset-ox }}-V_{\mathrm{FOC}}+4.8\right) \mathrm{eV} \\
& E_{\mathrm{LUMO}}(\text { electron affinity })=-\left(V_{\text {onset-red }}-V_{\mathrm{FOC}}+4.8\right) \mathrm{eV}
\end{aligned}
$$

Here, $V_{\mathrm{FOC}}$ is the potential value of $\mathrm{Fc} / \mathrm{Fc}+$ under the same experimental conditions $(0.52 \mathrm{~V})$ and $4.8 \mathrm{eV}$ is the HOMO energy 


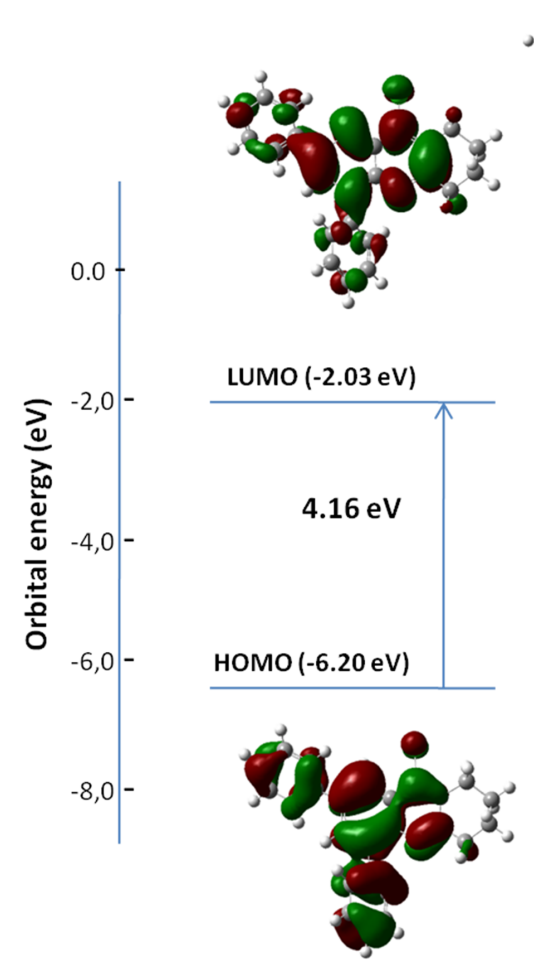

$4 a$
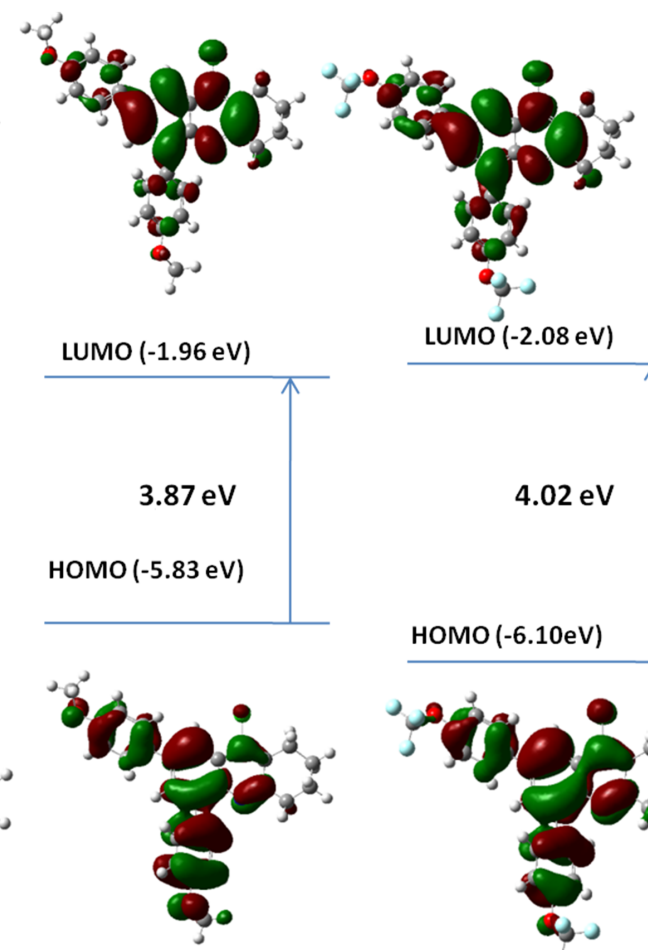

4b

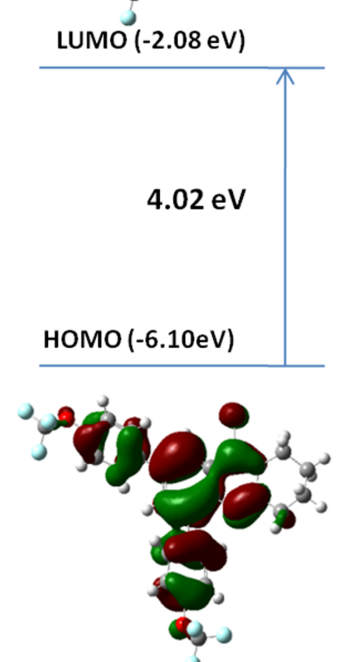

$4 c$

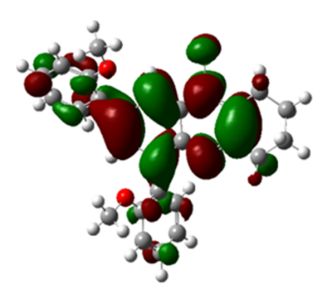

LUMO $(-1.62 \mathrm{eV})$

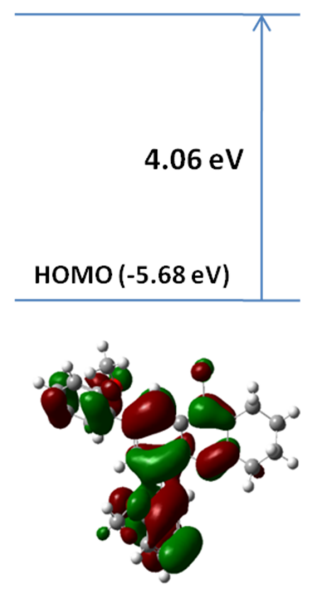

$4 d$

Figure 9: Calculated energy levels for compounds $4 a-d$ and their spatial distribution of the HOMO-LUMO frontier molecular orbitals from DFT calculations.

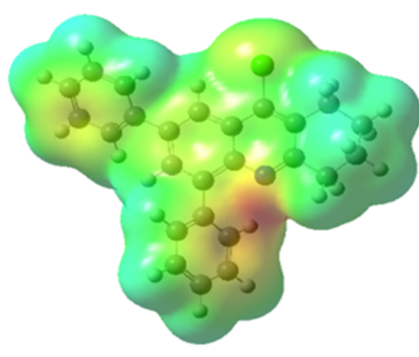

4a

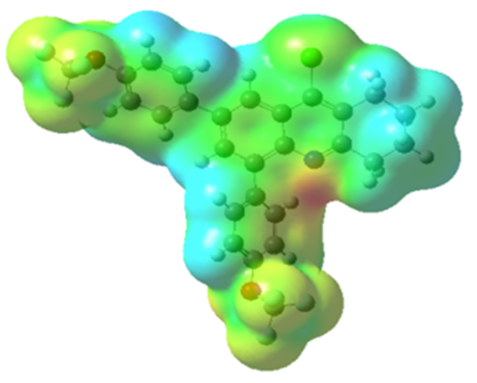

$4 c$

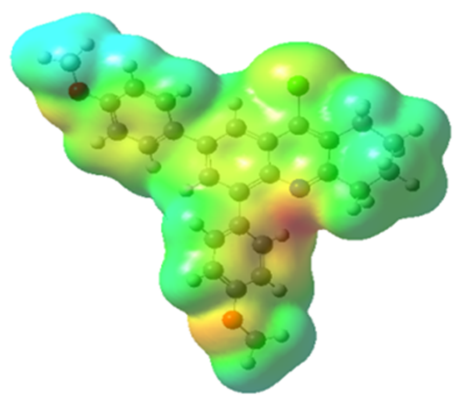

$4 b$

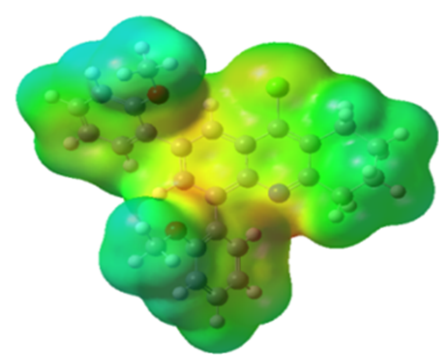

4d

Figure 10: Visualization of MEP for compounds 4a-d calculated by B3LYP method with 6-31G(d) basis set. 


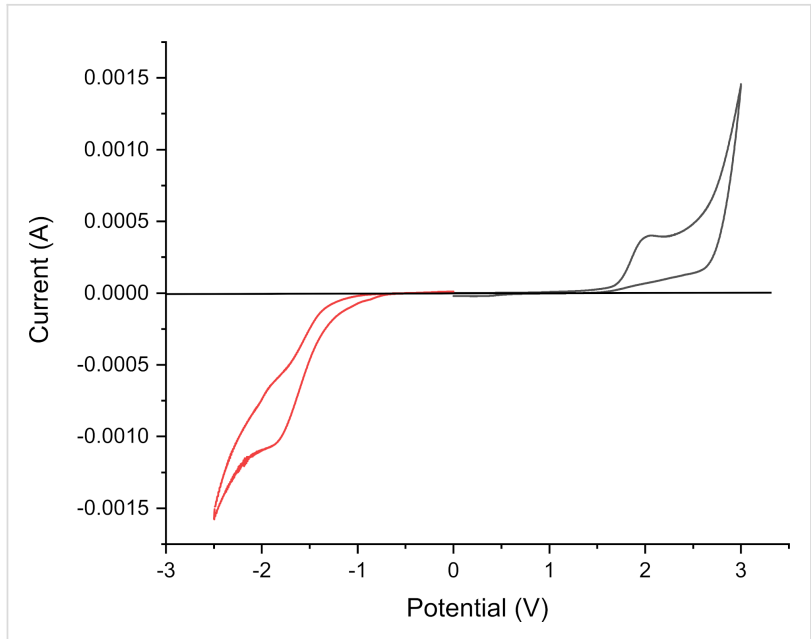

Figure 11: Cyclic voltammogram for $4 \mathrm{c}$ in $0.1 \mathrm{M}(n-\mathrm{Bu})_{4} \mathrm{NBF}_{4}$ /acetonitrile at a scan rate of $50 \mathrm{mV} / \mathrm{s}$.

value of $\mathrm{Fc} / \mathrm{Fc}+$ with respect to zero vacuum level. The onset potentials for the oxidation and reduction of $3 \mathrm{c}$ were $1.50 \mathrm{eV}$ and $-1.36 \mathrm{eV}$, respectively. Thus, their LUMO and the HOMO energies were found to be $-2.92 \mathrm{eV}$ and $-5.78 \mathrm{eV}$, respectively, giving rise to an electrochemical band gap of $2.86 \mathrm{eV}$. We noticed a difference of $0.23 \mathrm{eV}$ between the optical and the electrochemical band gap which is attributed to the interface barrier between the electrode and the tetrahydroacridine, as well as to the exciton binding energy $[68,69]$. On the other hand, the calculated HOMO energy was more negative than the experimental value, while the calculated LUMO energy was less negative. This can be explained by the fact that the calculations were achieved based on an equilibrium conformer.

\section{Conclusion}

In conclusion, we developed a convenient synthesis of novel 2,4-diaryl-9-chloro-5,6,7,8-tetrahydroacridines starting from commercially available anthranilic acid. Their photophysical properties show an impact of the aryl substituents on absorption and fluorescence. Methoxy substituents lead to a red shift of the emission and exhibited the highest fluorescence quantum yields. According to the theoretical studies, all products adopted a distorted molecular geometry. In contrast to methoxy groups, the trifluoromethoxy groups are twisted out of plane and, therefore, are not involved in the electronic orbital distribution. Experimental energy band gaps of the prepared tetrahydroacridines were found to be an average of $3 \mathrm{eV}$ which makes them promising candidates for optoelectronic applications.

\section{Experimental Materials and measurements}

Anhydrous solvents and chemicals were purchased from Sigma-Aldrich and used without further purification. All reac- tions were carried out under an inert argon atmosphere and were monitored by thin-layer chromatography (TLC). Organic compounds were purified using commercial Merck silica gel $(0.043-0.06 \mathrm{~mm})$ with a fluorescence indicator (the visualization was performed under UV light at $254 \mathrm{~nm}$ ). All solvents for work-up and column chromatography were distilled before use. NMR data were recorded in $\mathrm{CDCl}_{3}$ (tetramethylsilane as the internal standard) on Bruker ARX 300 instruments. Signals due to the solvent are: $\mathrm{CHCl}_{3}: \delta 7.26$ for ${ }^{1} \mathrm{H}$ and $\delta 77.16$ for ${ }^{13} \mathrm{C}$. Peak characterization of ${ }^{1} \mathrm{H}$ NMR spectra: $\mathrm{s}=$ singlet, $\mathrm{d}=$ doublet, $\mathrm{t}=$ triplet, $\mathrm{q}=$ quartet, $\mathrm{m}=$ multiplet. Chemical shifts were given in ppm $(\delta)$ relative to tetramethylsilane $\left(\mathrm{SiMe}_{4}\right)$ as internal standard. High-resolution MS (HRMS-ESI) was performed on an Agilent 1969 A TOF. The photophysical studies were carried out in freshly prepared dichloromethane solutions with concentrations of $1 \times 10^{-5} \mathrm{M}$. The UV-vis spectra were recorded on a Shimadzu $2401 \mathrm{PC}$ spectrophotometer in quartz cuvettes with a path length of $1 \mathrm{~cm}$. Emission spectra were recorded on a Perkin-Elmer LS 50B spectrofluorimeter. Cyclic voltammetry was performed in anhydrous acetonitrile solution containing $0.1 \mathrm{M}$ of tetrabutylammonium tetrafluoroborate $\left(n-\mathrm{Bu}_{4} \mathrm{NBF}_{4}\right)$ as a supporting electrolyte by using a three-electrode cell with a glassy carbon electrode as the working electrode, a platinum wire as the counter electrode, and an $\mathrm{Ag} / \mathrm{AgCl}$ electrode as the reference electrode. All the measurements were scanned in negative and positive directions at a scan rate of $50 \mathrm{mV} / \mathrm{s}$, as controlled by a PGSTAT30 Autolab potentiostat.

\section{Theoretical calculations}

The theoretical studies were realized in vacuum with the Gaussian 09 program [70]. The geometry of the equilibrium conformer at the ground state was first found at AM1 level. Then, further optimization through density functional theory (DFT) approach [71] at the restricted Becke, 3-parameter, Lee-Yang-Parr hybrid functional (B3LYP) with standard basis set 6-31G (d) were carried out.

\section{Experimental procedure for the Suzuki-Miyaura coupling and spectroscopic data for 9-chloro-2,4-diaryl-5,6,7,8- tetrahydroacridine derivatives $\mathbf{4 a - g}$}

2,4-Dibromo-9-chloro-5,6,7,8-tetrahydroacridine (2, $372.89 \mathrm{mg}$, $1 \mathrm{mmol}, 1$ equiv), phenylboronic acid (268.24 mg, $2.2 \mathrm{mmol}$, 2.2 equiv), $\mathrm{Pd}\left(\mathrm{PPh}_{3}\right)_{4}(11.55 \mathrm{mg}, 0.010 \mathrm{mmol}, 1 \mathrm{~mol} \%)$, and $\mathrm{K}_{3} \mathrm{PO}_{4}$ (849 mg, $4 \mathrm{mmol}$, 4 equiv) were added to a dried glass pressure tube. The tube was evacuated and backfilled three times with argon, then toluene $(5 \mathrm{~mL})$ was added. The tube was sealed with a Teflon cap and heated to $100{ }^{\circ} \mathrm{C}$ for $4 \mathrm{~h}$ until completion of the reaction (reaction progress was monitored by TLC). The mixture was then cooled to room temperature and 
the solvent was removed under reduced pressure. Water $(10 \mathrm{~mL})$ was added and extracted using $\mathrm{CH}_{2} \mathrm{Cl}_{2}(3 \times 10 \mathrm{~mL})$. The combined organic layers were dried $\left(\mathrm{Na}_{2} \mathrm{SO}_{4}\right)$ and the solvent was evaporated under reduced pressure. The crude product was purified by column chromatography using heptanes/ethyl acetate $9: 1$.

2,4-Diphenyl-9-chloro-5,6,7,8-tetrahydroacridine (4a): white solid; 95\%; mp 139-141 ${ }^{\circ} \mathrm{C}$; ${ }^{1} \mathrm{H}$ NMR $\left(300 \mathrm{MHz}, \mathrm{CDCl}_{3}\right) \delta$ 1.71-1.89 (m, 4H, 2CH $), 2.84-3.05\left(\mathrm{~m}, 4 \mathrm{H}, 2 \mathrm{CH}_{2}\right), 7.25-7.50$ (m, 6H, aryl-H), 7.66-7.71 (m, 4H, aryl-H), 7.91 (s, 1H, aryl$\mathrm{H}), 8.31$ (s, $1 \mathrm{H}$, aryl-H); ${ }^{13} \mathrm{C} \mathrm{NMR}\left(75 \mathrm{MHz}, \mathrm{CDCl}_{3}\right) \delta 22.6$ $\left(\mathrm{CH}_{2}\right), 22.7\left(\mathrm{CH}_{2}\right), 27.6\left(\mathrm{CH}_{2}\right), 34.3\left(\mathrm{CH}_{2}\right), 121.0\left(\mathrm{C}_{\mathrm{Ar}}\right), 126.0$ $\left(\mathrm{C}_{\mathrm{Ar}}\right), 127.4\left(\mathrm{C}_{\mathrm{Ar}}\right), 127.5\left(\mathrm{C}_{\mathrm{Ar}}\right), 127.8\left(\mathrm{C}_{\mathrm{Ar}}\right), 127.8\left(\mathrm{C}_{\mathrm{Ar}}\right), 128.9$ $\left(\mathrm{C}_{\mathrm{Ar}}\right), 129.0\left(\mathrm{C}_{\mathrm{Ar}}\right), 130.0\left(\mathrm{C}_{\mathrm{Ar}}\right), 131.0\left(\mathrm{C}_{\mathrm{Ar}}\right), 138.8\left(\mathrm{Cl}-\mathrm{C}_{\mathrm{Ar}}\right)$ $139.2\left(\mathrm{C}_{\mathrm{Ar}}\right), 140.3\left(\mathrm{C}_{\mathrm{Ar}}\right), 140.4\left(\mathrm{C}_{\mathrm{Ar}}\right), 141.8\left(\mathrm{C}_{\mathrm{Ar}}\right), 143.4$ $\left(\mathrm{N}-\mathrm{C}_{\mathrm{Ar}}\right), 159.1\left(\mathrm{~N}=\mathrm{C}_{\mathrm{Ar}}\right)$; HRMS-ESI $(\mathrm{m} / \mathrm{z}):[\mathrm{M}+\mathrm{H}]^{+}$calcd for $\mathrm{C}_{25} \mathrm{H}_{20} \mathrm{ClN}$, 370.1355; found, 370.1357.

2,4-Bis(4-methoxyphenyl)-9-chloro-5,6,7,8-tetrahydroacridine (4b): yellowish solid; (Hep/EA 9:1), 97\%; mp 135-137 ${ }^{\circ} \mathrm{C}$; ${ }^{1} \mathrm{H}$ NMR (300 MHz, $\left.\mathrm{CDCl}_{3}\right) \delta 1.91-1.99$ (m, 4H, $\left.2 \mathrm{CH}_{2}\right), 3.08-3.12\left(\mathrm{~m}, 4 \mathrm{H}, 2 \mathrm{CH}_{2}\right), 3.88\left(\mathrm{~s}, 3 \mathrm{H}, \mathrm{OCH}_{3}\right), 3.92(\mathrm{~s}$, $\left.3 \mathrm{H}, \mathrm{OCH}_{3}\right), 7.01-7.10(\mathrm{~m}, 4 \mathrm{H}$, aryl-H), 7.76-7.88 (m, 4H, aryl$\mathrm{H}), 7.92\left(\mathrm{~s}, 1 \mathrm{H}\right.$, aryl-H), $8.33\left(\mathrm{~s}, 1 \mathrm{H}\right.$, aryl-H); ${ }^{13} \mathrm{C} \mathrm{NMR}$ $\left(75 \mathrm{MHz}, \mathrm{CDCl}_{3}\right) \delta 22.7\left(\mathrm{CH}_{2}\right), 22.8\left(\mathrm{CH}_{2}\right), 26.5\left(\mathrm{CH}_{2}\right), 34.4$ $\left(\mathrm{CH}_{2}\right), 55.3\left(\mathrm{OCH}_{3}\right), 55.4\left(\mathrm{OCH}_{3}\right), 113.3\left(\mathrm{C}_{\mathrm{Ar}}\right), 114.4\left(\mathrm{C}_{\mathrm{Ar}}\right)$, $119.7\left(\mathrm{C}_{\mathrm{Ar}}\right), 126.1\left(\mathrm{C}_{\mathrm{Ar}}\right), 128.5\left(\mathrm{C}_{\mathrm{Ar}}\right), 128.8\left(\mathrm{C}_{\mathrm{Ar}}\right), 129.3\left(\mathrm{C}_{\mathrm{Ar}}\right)$, $131.8\left(\mathrm{C}_{\mathrm{Ar}}\right), 132.2\left(\mathrm{C}_{\mathrm{Ar}}\right), 133.0\left(\mathrm{C}_{\mathrm{Ar}}\right), 138.4\left(\mathrm{Cl}-\mathrm{C}_{\mathrm{Ar}}\right), 139.8$ $\left(\mathrm{C}_{\mathrm{Ar}}\right), 141.4\left(\mathrm{C}_{\mathrm{Ar}}\right), 143.5\left(\mathrm{C}_{\mathrm{Ar}}\right), 158.5\left(\mathrm{O}-\mathrm{C}_{\mathrm{Ar}}\right), 159.1\left(\mathrm{O}-\mathrm{C}_{\mathrm{Ar}}\right)$, $159.5\left(\mathrm{~N}=\mathrm{C}_{\mathrm{Ar}}\right)$; HRMS-ESI $(\mathrm{m} / \mathrm{z}):[\mathrm{M}+\mathrm{H}]^{+}$calcd for $\mathrm{C}_{27} \mathrm{H}_{24} \mathrm{ClNO}_{2}$, 430.1496; found, 430.1498.

2,4-Bis(4-trifluoromethoxyphenyl)-9-chloro-5,6,7,8-tetrahydroacridine (4c): white solid; (Hep/EA 9:1), 57\%; mp 127-129 ${ }^{\circ} \mathrm{C}$; ${ }^{1} \mathrm{H}$ NMR (300 MHz, $\mathrm{CDCl}_{3}$ ) $\delta 1.71-1.89(\mathrm{~m}, 4 \mathrm{H}$, 2 $\left.\mathrm{CH}_{2}\right), 2.91-2.99\left(\mathrm{~m}, 4 \mathrm{H}, 2 \mathrm{CH}_{2}\right), 7.11-7.27(\mathrm{~m}, 4 \mathrm{H}$, aryl-H), 7.66-7.88 (m, 4H, aryl-H), $7.72(\mathrm{~s}, 1 \mathrm{H}$, aryl-H), $8.23(\mathrm{~s}, 1 \mathrm{H}$, aryl-H); ${ }^{13} \mathrm{C} \mathrm{NMR}\left(75 \mathrm{MHz}, \mathrm{CDCl}_{3}\right) \delta 22.5\left(\mathrm{CH}_{2}\right), 22.6\left(\mathrm{CH}_{2}\right)$, $27.6\left(\mathrm{CH}_{2}\right), 34.5\left(\mathrm{CH}_{2}\right), 120.2\left(\mathrm{C}_{\mathrm{Ar}}\right), 121.5\left(\mathrm{C}_{\mathrm{Ar}}\right), 122.27$ $\left(\mathrm{CF}_{3} \mathrm{O}\right), 122.34\left(\mathrm{CF}_{3} \mathrm{O}\right), 126.0\left(\mathrm{C}_{\mathrm{Ar}}\right), 128.4\left(\mathrm{C}_{\mathrm{Ar}}\right), 128.8\left(\mathrm{C}_{\mathrm{Ar}}\right)$, $129.7\left(\mathrm{C}_{\mathrm{Ar}}\right), 132.0\left(\mathrm{C}_{\mathrm{Ar}}\right), 136.5\left(\mathrm{C}_{\mathrm{Ar}}\right), 137.3\left(\mathrm{C}_{\mathrm{Ar}}\right), 138.5\left(\mathrm{C}_{\mathrm{Ar}}\right)$, $139.1\left(\mathrm{Cl}-\mathrm{C}_{\mathrm{Ar}}\right), 141.5\left(\mathrm{C}_{\mathrm{Ar}}\right), 142.8\left(\mathrm{C}_{\mathrm{Ar}}\right), 143.0\left(\mathrm{C}_{\mathrm{Ar}}\right), 148.7$ $\left(\mathrm{O}-\mathrm{C}_{\mathrm{Ar}}\right), 149.8\left(\mathrm{O}-\mathrm{C}_{\mathrm{Ar}}\right), 159.7\left(\mathrm{~N}=\mathrm{C}_{\mathrm{Ar}}\right)$; HRMS-ESI $(\mathrm{m} / \mathrm{z})$ : $[\mathrm{M}+\mathrm{H}]^{+}$calcd for $\mathrm{C}_{27} \mathrm{H}_{18} \mathrm{ClF}_{6} \mathrm{NO}_{2}$, 538.0930; found, 538.0932 .

2,4-Bis(2-methoxyphenyl)-9-chloro-5,6,7,8-tetrahydroacridine (4d): yellowish paste; (Hep/EA 9:1), 92\%; mp 77-79 ${ }^{\circ} \mathrm{C}$;

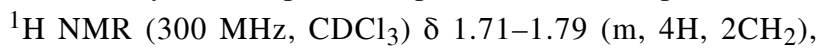
2.91-2.98 (m, 4H, 2CH $), 3.85\left(\mathrm{~s}, 3 \mathrm{H}, \mathrm{OCH}_{3}\right), 3.88(\mathrm{~s}, 3 \mathrm{H}$,
$\left.\mathrm{OCH}_{3}\right), 6.91-6.96(\mathrm{~m}, 4 \mathrm{H}$, aryl-H), 7.71-7.78 (m, 4H, aryl-H), $7.82\left(\mathrm{~s}, 1 \mathrm{H}\right.$, aryl-H), $8.23\left(\mathrm{~s}, 1 \mathrm{H}\right.$, aryl-H); ${ }^{13} \mathrm{C} \mathrm{NMR}(75 \mathrm{MHz}$, $\left.\mathrm{CDCl}_{3}\right) \delta 22.7\left(\mathrm{CH}_{2}\right), 22.7\left(\mathrm{CH}_{2}\right), 27.6\left(\mathrm{CH}_{2}\right), 34.4\left(\mathrm{CH}_{2}\right), 55.3$ $\left(\mathrm{OCH}_{3}\right), 55.4\left(\mathrm{OCH}_{3}\right), 113.7\left(\mathrm{C}_{\mathrm{Ar}}\right), 114.4\left(\mathrm{C}_{\mathrm{Ar}}\right), 119.7\left(\mathrm{C}_{\mathrm{Ar}}\right)$, $126.1\left(\mathrm{C}_{\mathrm{Ar}}\right), 128.5\left(\mathrm{C}_{\mathrm{Ar}}\right), 128.8\left(\mathrm{C}_{\mathrm{Ar}}\right), 129.3\left(\mathrm{C}_{\mathrm{Ar}}\right), 131.8\left(\mathrm{C}_{\mathrm{Ar}}\right)$, $132.1\left(\mathrm{C}_{\mathrm{Ar}}\right), 133.0\left(\mathrm{C}_{\mathrm{Ar}}\right), 138.4\left(\mathrm{Cl}-\mathrm{C}_{\mathrm{Ar}}\right), 139.8\left(\mathrm{C}_{\mathrm{Ar}}\right), 141.5$ $\left(\mathrm{C}_{\mathrm{Ar}}\right), 143.4\left(\mathrm{C}_{\mathrm{Ar}}\right), 158.5\left(\mathrm{O}-\mathrm{C}_{\mathrm{Ar}}\right), 159.1\left(\mathrm{O}-\mathrm{C}_{\mathrm{Ar}}\right), 159.5$ $\left(\mathrm{N}=\mathrm{C}_{\mathrm{Ar}}\right)$; HRMS-ESI $(\mathrm{m} / \mathrm{z}):[\mathrm{M}+\mathrm{H}]^{+}$calcd for $\mathrm{C}_{27} \mathrm{H}_{24} \mathrm{ClNO}_{2}$, 430.1495; found, 430.1493 .

2,4-Bis(4-ethylphenyl)-9-chloro-5,6,7,8-tetrahydroacridine (4e): pale green solid; $90 \%$; mp $120-122{ }^{\circ} \mathrm{C}$; ${ }^{1} \mathrm{H}$ NMR (300 MHz, $\left.\mathrm{CDCl}_{3}\right) \delta 1.31-1.45\left(\mathrm{~m}, 6 \mathrm{H}, 2 \mathrm{CH}_{3}\right), 1.81-2.07(\mathrm{~m}$, $\left.4 \mathrm{H}, 2 \mathrm{CH}_{2}\right), 2.67-2.85\left(\mathrm{~m}, 4 \mathrm{H}, 2 \mathrm{CH}_{2}\right), 3.07-3.25(\mathrm{~m}, 4 \mathrm{H}$, $\left.2 \mathrm{CH}_{2}\right), 7.35-7.45(\mathrm{~m}, 4 \mathrm{H}$, aryl-H), 7.63-7.75 (m, 4H, aryl-H), $8.10\left(\mathrm{~s}, 1 \mathrm{H}\right.$, aryl-H), $8.44\left(\mathrm{~s}, 1 \mathrm{H}\right.$, aryl-H); ${ }^{13} \mathrm{C} \mathrm{NMR}(75 \mathrm{MHz}$, $\left.\mathrm{CDCl}_{3}\right) \delta 15.6\left(\mathrm{CH}_{3}\right), 15.7\left(\mathrm{CH}_{3}\right), 22.7\left(\mathrm{CH}_{2}\right), 22.8\left(\mathrm{CH}_{2}\right), 27.6$ $\left(\mathrm{CH}_{2}\right), 28.6\left(\mathrm{CH}_{2}\right), 28.8\left(\mathrm{CH}_{2}\right), 34.5\left(\mathrm{CH}_{2}\right), 120.5\left(\mathrm{C}_{\mathrm{Ar}}\right), 126.1$ $\left(\mathrm{C}_{\mathrm{Ar}}\right), 127.0\left(\mathrm{C}_{\mathrm{Ar}}\right), 127.4\left(\mathrm{C}_{\mathrm{Ar}}\right), 127.5\left(\mathrm{C}_{\mathrm{Ar}}\right), 128.3\left(\mathrm{C}_{\mathrm{Ar}}\right), 128.8$ $\left(\mathrm{C}_{\mathrm{Ar}}\right), 129.7\left(\mathrm{C}_{\mathrm{Ar}}\right), 131.1\left(\mathrm{C}_{\mathrm{Ar}}\right), 136.8\left(\mathrm{C}_{\mathrm{Ar}}\right), 138.0\left(\mathrm{Cl}-\mathrm{C}_{\mathrm{Ar}}\right)$, $138.8\left(\mathrm{C}_{\mathrm{Ar}}\right), 140.4\left(\mathrm{C}_{\mathrm{Ar}}\right), 141.5\left(\mathrm{C}_{\mathrm{Ar}}\right), 143.1\left(\mathrm{C}_{\mathrm{Ar}}\right), 144.0$ $\left(\mathrm{N}-\mathrm{C}_{\mathrm{Ar}}\right), 158.8\left(\mathrm{~N}=\mathrm{C}_{\mathrm{Ar}}\right)$; HRMS-ESI $(\mathrm{m} / \mathrm{z}):[\mathrm{M}+\mathrm{H}]^{+}$calcd for $\mathrm{C}_{29} \mathrm{H}_{28} \mathrm{ClN}$, 426.1910; found, 426.1913.

\section{2,4-Bis(2-phenylphenyl)-9-chloro-5,6,7,8-tetrahydroacri-} dine (4f): yellowish solid; $85 \%$; mp $94-96{ }^{\circ} \mathrm{C}$; ${ }^{1} \mathrm{H}$ NMR (300 MHz, $\left.\mathrm{CDCl}_{3}\right) \delta$ 1.44-1.69 (m, 4H, 2 $\left.\mathrm{CH}_{2}\right), 2.54-2.65(\mathrm{~m}$, $\left.4 \mathrm{H}, 2 \mathrm{CH}_{2}\right), 6.77-6.89(\mathrm{~m}, 6 \mathrm{H}$, aryl-H), 6.96-7.18 (m, 6H, aryl$\mathrm{H}), 7.29-7.44(\mathrm{~m}, 6 \mathrm{H}$, aryl-H), $7.81(\mathrm{~s}, 1 \mathrm{H}$, aryl-H), $8.11(\mathrm{~s}, 1 \mathrm{H}$, aryl-H); ${ }^{13} \mathrm{C} \mathrm{NMR}\left(75 \mathrm{MHz}, \mathrm{CDCl}_{3}\right) \delta 22.5\left(\mathrm{CH}_{2}\right), 22.6\left(\mathrm{CH}_{2}\right)$, $27.6\left(\mathrm{CH}_{2}\right), 35.5\left(\mathrm{CH}_{2}\right), 119.8\left(\mathrm{C}_{\mathrm{Ar}}\right), 123.5\left(\mathrm{C}_{\mathrm{Ar}}\right), 123.9\left(\mathrm{C}_{\mathrm{Ar}}\right)$, $124.5\left(\mathrm{C}_{\mathrm{Ar}}\right), 125.0\left(\mathrm{C}_{\mathrm{Ar}}\right), 125.4\left(\mathrm{C}_{\mathrm{Ar}}\right), 125.8\left(\mathrm{C}_{\mathrm{Ar}}\right), 126.1\left(\mathrm{C}_{\mathrm{Ar}}\right)$, $126.9\left(\mathrm{C}_{\mathrm{Ar}}\right), 127.2\left(\mathrm{C}_{\mathrm{Ar}}\right), 127.6\left(\mathrm{C}_{\mathrm{Ar}}\right), 127.9\left(\mathrm{C}_{\mathrm{Ar}}\right), 128.1\left(\mathrm{C}_{\mathrm{Ar}}\right)$, $129.1\left(\mathrm{C}_{\mathrm{Ar}}\right), 129.9\left(\mathrm{C}_{\mathrm{Ar}}\right), 130.1\left(\mathrm{C}_{\mathrm{Ar}}\right), 130.7\left(\mathrm{C}_{\mathrm{Ar}}\right), 131.6\left(\mathrm{C}_{\mathrm{Ar}}\right)$, $134.2\left(\mathrm{C}_{\mathrm{Ar}}\right), 137.1\left(\mathrm{C}_{\mathrm{Ar}}\right), 138.5\left(\mathrm{Cl}-\mathrm{C}_{\mathrm{Ar}}\right), 139.5\left(\mathrm{C}_{\mathrm{Ar}}\right), 140.1$ $\left(\mathrm{C}_{\mathrm{Ar}}\right), 140.8\left(\mathrm{C}_{\mathrm{Ar}}\right), 141.5\left(\mathrm{C}_{\mathrm{Ar}}\right), 143.1\left(\mathrm{~N}-\mathrm{C}_{\mathrm{Ar}}\right), 158.2\left(\mathrm{C}_{\mathrm{Ar}}\right)$, $159.0\left(\mathrm{C}_{\mathrm{Ar}}\right), 160.6\left(\mathrm{~N}=\mathrm{C}_{\mathrm{Ar}}\right)$; HRMS-ESI $(\mathrm{m} / \mathrm{z}):[\mathrm{M}+\mathrm{H}]^{+}$calcd for $\mathrm{C}_{37} \mathrm{H}_{28} \mathrm{ClN}$, 522.1910; found, 522.1912.

\section{2,4-Bis(2-ethylphenyl)-9-chloro-5,6,7,8-tetrahydroacridine} (4g): brown solid; 88\%; mp 186-188 ${ }^{\circ} \mathrm{C}$; ${ }^{1} \mathrm{H}$ NMR (300 MHz, $\left.\mathrm{CDCl}_{3}\right) \delta 1.35-1.47\left(\mathrm{~m}, 6 \mathrm{H}, 2 \mathrm{CH}_{3}\right), 1.79-1.95\left(\mathrm{~m}, 4 \mathrm{H}, 2 \mathrm{CH}_{2}\right)$, 2.62-2.83 (m, 4H, 2CH $), 3.11-3.29\left(\mathrm{~m}, 4 \mathrm{H}, 2 \mathrm{CH}_{2}\right), 7.25-7.35$ $(\mathrm{m}, 4 \mathrm{H}$, aryl-H), 7.61-7.71 (m, 4H, aryl-H), 8.12 (s, 1H, aryl$\mathrm{H}), 8.43\left(\mathrm{~s}, 1 \mathrm{H}\right.$, aryl-H); ${ }^{13} \mathrm{C}$ NMR $\left(75 \mathrm{MHz}, \mathrm{CDCl}_{3}\right) \delta 15.5$ $\left(\mathrm{CH}_{3}\right), 15.6\left(\mathrm{CH}_{3}\right), 22.7\left(\mathrm{CH}_{2}\right), 22.8\left(\mathrm{CH}_{2}\right), 27.5\left(\mathrm{CH}_{2}\right), 28.5$ $\left(\mathrm{CH}_{2}\right), 28.7\left(\mathrm{CH}_{2}\right), 34.4\left(\mathrm{CH}_{2}\right), 120.3\left(\mathrm{C}_{\mathrm{Ar}}\right), 126.0\left(\mathrm{C}_{\mathrm{Ar}}\right), 126.3$ $\left(\mathrm{C}_{\mathrm{Ar}}\right), 127.2\left(\mathrm{C}_{\mathrm{Ar}}\right), 127.1\left(\mathrm{C}_{\mathrm{Ar}}\right), 127.6\left(\mathrm{C}_{\mathrm{Ar}}\right), 128.2\left(\mathrm{C}_{\mathrm{Ar}}\right), 128.7$ $\left(\mathrm{C}_{\mathrm{Ar}}\right), 129.0\left(\mathrm{C}_{\mathrm{Ar}}\right), 129.6\left(\mathrm{C}_{\mathrm{Ar}}\right), 131.1\left(\mathrm{C}_{\mathrm{Ar}}\right), 131.8\left(\mathrm{C}_{\mathrm{Ar}}\right), 136.8$ $\left(\mathrm{C}_{\mathrm{Ar}}\right), 138.1\left(\mathrm{Cl}-\mathrm{C}_{\mathrm{Ar}}\right), 138.2\left(\mathrm{C}_{\mathrm{Ar}}\right), 138.9\left(\mathrm{C}_{\mathrm{Ar}}\right), 140.5\left(\mathrm{C}_{\mathrm{Ar}}\right)$, $141.4\left(\mathrm{C}_{\mathrm{Ar}}\right), 143.4\left(\mathrm{C}_{\mathrm{Ar}}\right), 144.1\left(\mathrm{~N}-\mathrm{C}_{\mathrm{Ar}}\right), 158.9\left(\mathrm{~N}=\mathrm{C}_{\mathrm{Ar}}\right)$; 
HRMS-ESI $(\mathrm{m} / \mathrm{z}):[\mathrm{M}+\mathrm{H}]^{+}$calcd for $\mathrm{C}_{29} \mathrm{H}_{28} \mathrm{ClN}$, 426.1910; found, 426.1914.

\section{Supporting Information}

\section{Supporting Information File 1}

Synthesis and analytical data of starting compound $\mathbf{2}$ and copies of spectra for the synthesized compounds. [https://www.beilstein-journals.org/bjoc/content/ supplementary/1860-5397-17-162-S1.pdf]

\section{Funding}

This study was supported by the Ministry of Higher Education and Scientific Research-Tunisia. Financial support from the DAAD (scholarship for N. T.) is gratefully acknowledged.

\section{ORCID ${ }^{\circledR} \mathrm{iDs}$}

Najeh Tka - https://orcid.org/0000-0002-2560-7576

Mohamed Adnene Hadj Ayed - https://orcid.org/0000-0001-8919-2405 Peter Langer - https://orcid.org/0000-0002-7665-8912

\section{References}

1. Hoang, M. H.; Cho, M. J.; Kim, K. H.; Cho, M. Y.; Joo, J.-s.; Choi, D. H. Thin Solid Films 2009, 518, 501-506. doi:10.1016/j.tsf.2009.07.030

2. Payne, A.-J.; McCahill, J. S. J.; Welch, G. C. Dyes Pigm. 2015, 123, 139-146. doi:10.1016/j.dyepig.2015.07.035

3. Pham, H. T.; Lee, D.-S.; Dao, T. D.; Jeong, H.-D.

J. Ind. Eng. Chem. (Amsterdam, Neth.) 2018, 57, 22-27. doi:10.1016/j.jiec.2017.08.003

4. Fujita, T.; Haketa, Y.; Maeda, H.; Yamamoto, T. Org. Electron. 2017, 49, 53-63. doi:10.1016/j.orgel.2017.06.028

5. Ma, L.; Yu, Y.; Li, L.; Lei, T.; Jiao, B.; Hou, X.; Wu, Z. Org. Electron. 2018, 57, 123-132. doi:10.1016/j.orgel.2018.02.042

6. Zhao, Q.; Yuan, H.; Xu, X.; Hu, L.; Gong, P.; Yan, Z. Dyes Pigm. 2019, 165, 217-222. doi:10.1016/j.dyepig.2019.02.030

7. Yan, Z.; Wang, C.; Tang, Y.; Zhu, Y.; Cao, Q.; Yang, T.; Hu, L. Spectrochim. Acta, Part A 2020, 224, 117451. doi:10.1016/j.saa.2019.117451

8. Reddy, G.; Basak, P.; Jones, L. A.; Della Gaspera, E.; Islavath, N.; Giribabu, L. Sol. Energy 2020, 206, 539-547. doi:10.1016/j.solener.2020.06.040

9. Hong, T. R.; Shin, J.; Um, H. A.; Lee, T. W.; Cho, M. J.; Kim, G. W.; Kwon, J. H.; Choi, D. H. Dyes Pigm. 2014, 108, 7-14. doi:10.1016/j.dyepig.2014.04.015

10. Sun, Z.-Z.; Sun, P.-P.; Feng, S.; Xu, Y.-L.; Liu, J.-F. Synth. Met. 2019, 254, 34-41. doi:10.1016/j.synthmet.2019.05.014

11. Kumar, R.; Kaur, M.; Kumari, M. Acta Pol. Pharm. 2012, 69, 3-9.

12. Schmidt, A.; Liu, M. Adv. Heterocycl. Chem. 2015, 115, 287-353. doi:10.1016/bs.aihch.2015.04.004

13. Ježek, J.; Hlaváček, J.; Šebestík, J. Syntheses. In Biomedical Applications of Acridines; Progress in Drug Research; Rainsford, R. D., Ed.; Springer: Cham, Switzerland, 2017; Vol. 72, pp 9-45. doi:10.1007/978-3-319-63953-6_3
14. Songbuer; Li, M.; Imerhasan, M. Chin. J. Org. Chem. 2018, 38, 594. doi:10.6023/cjoc201710007

15. Demeunynck, M.; Charmantray, F.; Martelli, A. Curr. Pharm. Des. 2001, 7, 1703-1724. doi:10.2174/1381612013397131

16. Dopierała, A.; Wrosz, P.; Mazerski, J. Postepy Hig. Med. Dosw. 2011, 65, 263-269. doi:10.5604/17322693.941521

17. Galdino-Pitta, M. R.; Pitta, M. G. R.; Lima, M. C. A.; Galdino, L. S.; Pitta, I. R. Mini-Rev. Med. Chem. 2013, 13, 1256-1271. doi:10.2174/1389557511313090002

18. Denny, W. A. Curr. Med. Chem. 2002, 9, 1655-1665. doi:10.2174/0929867023369277

19. Valdés, A. F.-C. Open Med. Chem. J. 2011, 5, 11-20. doi:10.2174/1874104501105010011

20. Sondhi, S. M.; Singh, J.; Rani, R.; Gupta, P. P.; Agrawal, S. K. Saxena, A. K. Eur. J. Med. Chem. 2010, 45, 555-563. doi:10.1016/j.ejmech.2009.10.042

21. Benoit, A. R.; Schiaffo, C.; Salomon, C. E.; Goodell, J. R.; Hiasa, H.; Ferguson, D. M. Bioorg. Med. Chem. Lett. 2014, 24, 3014-3017. doi:10.1016/j.bmcl.2014.05.037

22. Cholewiński, G.; Dzierzbicka, K.; Kołodziejczyk, A. M. Pharmacol. Rep. 2011, 63, 305-336. doi:10.1016/s1734-1140(11)70499-6

23. Singh, H.; Singh, H.; Sharma, S.; Bedi, P. M. S. Heterocycles 2015, 91 , 2043-2085. doi:10.3987/rev-15-826

24. Chatterjee, S.; Kumar, G. S. J. Photochem. Photobiol., B 2016, 159, 169-178. doi:10.1016/j.jphotobiol.2016.03.045

25. Jiao, J.; Shen, J.; Wang, L.; Xie, Z.; Xia, C.; Xin, X. Colloids Surf., A 2018, 545, 8-15. doi:10.1016/j.colsurfa.2018.02.013

26. Gadah, R. H.; Basaleh, A. S. Ceram. Int. 2020, 46, 1690-1696. doi:10.1016/j.ceramint.2019.09.141

27. Dai, Q.; Gao, C.; Liu, Y.; Liu, H.; Xiao, B.; Chen, C.; Chen, J.; Yuan, Z.; Jiang, Y. Tetrahedron 2018, 74, 6459-6464. doi:10.1016/j.tet.2018.09.027

28. Wang, C.; Fu, J.; Yao, K.; Xue, K.; Xu, K.; Pang, X. Spectrochim. Acta, Part A 2018, 199, 403-411. doi:10.1016/j.saa.2018.03.015

29. Bazzicalupi, C.; Bencini, A.; Matera, I.; Puccioni, S.; Valtancoli, B. Inorg. Chim. Acta 2012, 381, 162-169. doi:10.1016/j.ica.2011.08.057

30. Goel, A.; Kumar, V.; Singh, S. P.; Sharma, A.; Prakash, S.; Singh, C.; Anand, R. S. J. Mater. Chem. 2012, 22, 14880. doi:10.1039/c2jm31052j

31. Boudreault, P.-L. T.; Alleyne, B.; Xia, C. Organic electroluminescent materials and devices. U.S. Pat. Appl. US2018/0013077A1, Jan 11, 2018.

32. Wiseman, A.; Sims, L. A.; Snead, R.; Gronert, S.; Maclagan, R. G. A. R.; Meot-Ner (Mautner), M. J. Phys. Chem. A 2015, 119, 118-126. doi:10.1021/jp506913r

33. Gong, X.; Lu, C.-H.; Lee, W.-K.; Li, P.; Huang, Y.-H.; Chen, Z.; Zhan, L.; Wu, C.-C.; Gong, S.; Yang, C. Chem. Eng. J. 2021, 405, 126663. doi:10.1016/j.cej.2020.126663

34. Chen, J.-X.; Tao, W.-W.; Wang, K.; Zheng, C.-J.; Liu, W.; Li, X.; Ou, X.-M.; Zhang, X.-H. Org. Electron. 2018, 57, 327-334. doi:10.1016/j.orgel.2018.03.024

35. Stępień, M.; Gońka, E.; Żyła, M.; Sprutta, N. Chem. Rev. 2017, 117, 3479-3716. doi:10.1021/acs.chemrev.6b00076

36. Yang, W.; Monteiro, J. H. S. K.; de Bettencourt-Dias, A.; Catalano, V. J.; Chalifoux, W. A. Chem. - Eur. J. 2019, 25, 1441-1445. doi:10.1002/chem.201805248

37. Zhang, J.; Lakowicz, J. R. J. Phys. Chem. B 2005, 109, 8701-8706. doi:10.1021/jp046016 
38. Sun, W.; Zhou, N.; Xiao, Y.; Wang, S.; Li, X. Dyes Pigm. 2018, 154 30-37. doi:10.1016/j.dyepig.2018.02.041

39. Kim, M.; Lee, J. Y. Org. Electron. 2012, 13, 1245-1249. doi:10.1016/j.orgel.2012.03.040

40. Seo, J.-A.; Jeon, S. K.; Lee, J. Y. Org. Electron. 2016, 34, 33-37. doi:10.1016/j.orgel.2016.03.038

41. Wang, Z.; Zhang, H.; Wang, Z.; Zhao, B.; Chen, L.; Li, J.; Wang, H.; Hao, Y.; Li, W. Org. Electron. 2018, 57, 311-316. doi:10.1016/j.orgel.2018.03.031

42. Han, M.; Chen, Y.; Xie, Y.; Zhang, F.; Li, X.; Huang, A.; Fan, Y.; Fan, Y.; Gong, Y.; Peng, Q.; Li, Q.; Ma, D.; Li, Z. Cell Rep. Phys. Sci. 2020, 1, 100252. doi:10.1016/j.xcrp.2020.100252

43. Zeng, W.; Lai, H.-Y.; Lee, W.-K.; Jiao, M.; Shiu, Y.-J.; Zhong, C.; Gong, S.; Zhou, T.; Xie, G.; Sarma, M.; Wong, K.-T.; Wu, C.-C.; Yang, C. Adv. Mater. (Weinheim, Ger.) 2018, 30, 1704961. doi:10.1002/adma.201704961

44. Szymański, P.; Markowicz, M.; Mikiciuk-Olasik, E. Bioorg. Chem. 2011, 39, 138-142. doi:10.1016/j.bioorg.2011.05.001

45. Pirrung, M. C.; Chau, J. H.-L.; Chen, J. Chem. Biol. 1995, 2, 621-626. doi:10.1016/1074-5521(95)90127-2

46. Czarnecka, K.; Chufarova, N.; Halczuk, K.; Maciejewska, K.; Girek, M.; Skibiński, R.; Jończyk, J.; Bajda, M.; Kabziński, J.; Majsterek, I.; Szymański, P. Eur. J. Med. Chem. 2018, 145, 760-769. doi:10.1016/j.ejmech.2018.01.014

47. Bajda, M.; Jończyk, J.; Malawska, B.; Czarnecka, K.; Girek, M.; Olszewska, P.; Sikora, J.; Mikiciuk-Olasik, E.; Skibiński, R.; Gumieniczek, A.; Szymański, P. Bioorg. Med. Chem. 2015, 23, 5610-5618. doi:10.1016/j.bmc.2015.07.029

48. Nishibori, M.; Oishi, R.; Itoh, Y.; Saeki, K. Jpn. J. Pharmacol. 1991, 55 , 539-546. doi:10.1016/s0021-5198(19)39924-X

49. Liu, Z.; Fang, L.; Zhang, H.; Gou, S.; Chen, L. Bioorg. Med. Chem. 2017, 25, 2387-2398. doi:10.1016/j.bmc.2017.02.049

50. Romero, A.; Cacabelos, R.; Oset-Gasque, M. J.; Samadi, A.; Marco-Contelles, J. Bioorg. Med. Chem. Lett. 2013, 23, 1916-1922. doi:10.1016/j.bmcl.2013.02.017

51. Martins, C.; Carreiras, M. C.; León, R.; de los Ríos, C.; Bartolini, M.; Andrisano, V.; Iriepa, I.; Moraleda, I.; Gálvez, E.; García, M.; Egea, J.; Samadi, A.; Chioua, M.; Marco-Contelles, J. Eur. J. Med. Chem. 2011, 46, 6119-6130. doi:10.1016/j.ejmech.2011.09.038

52. Olszewska, P.; Mikiciuk-Olasik, E.; Błaszczak-Świątkiewicz, K.; Szymański, J.; Szymański, P. Biomed. Pharmacother. 2014, 68, 959-967. doi:10.1016/j.biopha.2014.10.018

53. Wang, S.-L.; Wang, Z.-F.; Qin, Q.-P.; Tan, M.-X.; Luo, D.-M.; Zou, B.-Q.; Liu, Y.-C. Inorg. Chem. Commun. 2019, 99, 77-81. doi:10.1016/j.inoche.2018.11.012

54. Tripathi, R. P.; Verma, S. S.; Pandey, J.; Agarwal, K. C.; Chaturvedi, V.; Manju, Y. K.; Srivastva, A. K.; Gaikwad, A.; Sinha, S. Bioorg. Med. Chem. Lett. 2006, 16, 5144-5147. doi:10.1016/j.bmcl.2006.07.025

55. Flader, A.; Ohlendorf, L.; Ehlers, P.; Ammon, E.; Villinger, A.; Langer, P. Adv. Synth. Catal. 2019, 361, 2981-2991. doi:10.1002/adsc.201900034

56. Janke, J.; Villinger, A.; Ehlers, P.; Langer, P. Synlett 2019, 30, 817-820. doi:10.1055/s-0037-1612256

57. Tka, N.; Ayed, M. A. H.; Braiek, M. B.; Jabli, M.; Chaaben, N.; Alimi, K.; Jopp, S.; Langer, P. Beilstein J. Org. Chem. 2021, 17, 1629-1640. doi:10.3762/bjoc.17.115

58. Tka, N.; Jabli, M.; Saleh, T. A.; Salman, G. A. J. Mol. Liq. 2018, 250, 423-432. doi:10.1016/j.molliq.2017.12.026
59. Jabli, M.; Tka, N.; Ramzi, K.; Saleh, T. A. J. Mol. Liq. 2018, 249 , 1138-1144. doi:10.1016/j.molliq.2017.11.126

60. Jabli, M.; Tka, N.; Salman, G. A.; Elaissi, A.; Sebeia, N.; Hamdaoui, M. J. Mol. Liq. 2017, 242, 272-283. doi:10.1016/j.molliq.2017.07.018

61. Modh, R. P.; De Clercq, E.; Pannecouque, C.; Chikhalia, K. H. J. Enzyme Inhib. Med. Chem. 2014, 29, 100-108. doi:10.3109/14756366.2012.755622

62. Keri, R. S.; Quintanova, C.; Marques, S. M.; Esteves, A. R.; Cardoso, S. M.; Santos, M. A. Bioorg. Med. Chem. 2013, 21, 4559-4569. doi:10.1016/j.bmc.2013.05.028

63. Miyaura, N.; Yamada, K.; Suzuki, A. Tetrahedron Lett. 1979, 20 , 3437-3440. doi:10.1016/s0040-4039(01)95429-2

64. Miyaura, N.; Suzuki, A. J. Chem. Soc., Chem. Commun. 1979, 866-867. doi:10.1039/c39790000866

65. Qin, Y.; Gu, H.; Liu, S.; Dai, W.; Luo, X. Synth. Met. 2018, 245, 42-50. doi:10.1016/j.synthmet.2018.08.008

66. Melhuish, W. H. J. Phys. Chem. 1961, 65, 229-235. doi:10.1021/j100820a009

67. Connelly, N. G.; Geiger, W. E. Chem. Rev. 1996, 96, 877-910. doi:10.1021/cr940053x

68. Egbe, D. A. M.; Carbonnier, B.; Paul, E. L.; Mühlbacher, D.; Kietzke, T.; Birckner, E.; Neher, D.; Grummt, U.-W.; Pakula, T. Macromolecules 2005, 38, 6269-6275. doi:10.1021/ma0507490

69. Zahn, D. R. T.; Gavrila, G. N.; Salvan, G. Chem. Rev. 2007, 107, 1161-1232. doi:10.1021/cr050141p

70. Gaussian 09, Revision B.01; Gaussian, Inc.: Wallingford, CT, USA, 2009.

71. Koch, M. W.; Holthausen, C. A. Chemist's Guide to Density Functional Theory, 1st ed.; Wiley-VCH: Weinheim, Germany, 2000. doi:10.1002/3527600043

\section{License and Terms}

This is an Open Access article under the terms of the Creative Commons Attribution License (https://creativecommons.org/licenses/by/4.0). Please note that the reuse, redistribution and reproduction in particular requires that the author(s) and source are credited and that individual graphics may be subject to special legal provisions.

The license is subject to the Beilstein Journal of Organic Chemistry terms and conditions: (https://www.beilstein-journals.org/bjoc/terms)

The definitive version of this article is the electronic one which can be found at: https://doi.org/10.3762/bjoc. 17.162 